\title{
Chemical characteristics of organic wastes and their potential use for acid mine drainage remediation
}

\author{
Ali Munawar*) and Riwandi \\ Soil Science Laboratory, Faculty of Agriculture, the University of Bengkulu \\ Jl. W.R. Supratman, Bengkulu 38371
}

Diterima 21-08-2009

Disetujui 12-11-2009

\begin{abstract}
Organic substrate is an important component of biological treatments for acid mine drainage (AMD) remediation systems. It provides organic substrates to sulfate-reducing bacteria (SRB) in the sulfate (SO4) reduction, resulting in increased alkalinity and metal sulfide precipitates. Natural organic matters vary in their characteristics, and therefore may perform differently for remediation properties. This study was aimed to characterize four locally available organic wastes (bark, empty fruit bunch, sawdust, and chicken manure) potential for AMD remediation. Their chemical properties and elemental compositions were measured. An anaerobic incubation of these wastes in AMD was undertaken to determine their remediation properties. The $\mathrm{pH}$, electrical conductivity (EC), redox potential (Eh), and dissolved Fe and $\mathrm{SO}_{4}$ of the mixtures were measured after the 1st, 7th, 14th, and 30th day of the incubation at room temperature. The results demonstrated that organic wastes varied in their chemical properties and performed differently in treating AMD. Organic wastes containing high alkalinity (high $\mathrm{pH}$ ) and nutrient concentrations (chicken manure and empty fruit bunch) improved AMD quality through increasing $\mathrm{pH}(>6)$ and reducing dissolved Fe and $\mathrm{SO} 4$ concentrations. Although sawdust and bark (high $\mathrm{CEC}$ ) did not increase $\mathrm{pH}$ up to acceptable standard at most time, they apparently were able to remove dissolved Fe from AMD through adsorption mechanism.
\end{abstract}

Keywords: acid mine drainage, anaerobic incubation, organic wastes, remediation.

\section{INTRODUCTION}

Acid mine drainage (AMD) is one of most serious problems facing mine industries worldwide, including coal industry in Indonesia. This is due to its high acidity ( $\mathrm{pH}$ can be as low as 2) and elevated concentrations of dissolved metals and sulfates which are potentially hazardous to the environment, especially aquatic systems Therefore it should be treated before being discharged to water.

A number of techniques have been developed to reduce acidity and dissolved metals and sulfate concentrations. A promising and increasingly accepted method is biological treatment systems, such as constructed wetlands and bioreactors. These biological approaches involve the use of organic materials and anaerobic sulfate-reducing bacteria (SRB) which reduce sulfate to sulfide by oxidizing the organic carbon source (Gibert et al., 2004; Liamleam \& Annachhatre 2007). The sulfate reduction into sulfide is described in the following reaction:

*Telp: 081227757795

Email: a.munawar008@gmail.com

$$
\mathrm{SO}_{4}{ }^{2-}+2 \mathrm{CH}_{2} \mathrm{O} \rightarrow \mathrm{H}_{2} \mathrm{~S}+2 \mathrm{HCO}_{3}^{-} \text {, }
$$

$\mathrm{CH}_{2} \mathrm{O}$ represents a simple organic carbon (C). Sulfate reduction reactions consume $\mathrm{SO}_{4}{ }^{2-}$, produce $\mathrm{H}_{2} \mathrm{~S}$, and result in increased alkalinity and $\mathrm{pH}$. The released bicarbonate neutralizes the acidity, increases the alkalinity of $A M D$, and enhances precipitation of metal carbonates minerals. In the presence of metal ions, as generally found in AMD, the released $\mathrm{H}_{2} \mathrm{~S}$ will react to form insoluble metal sulfides, removing sufates from the water (Drury 1999; Luptakova \& Kusnierova 2005; Machemer \& Wildeman 1992; Song et al., 2001; Zagury et al., 2006). A reaction between sulfides and metal ions can be described as follows:

$$
\mathrm{Me}^{2+}+\mathrm{S}^{2-} \quad \rightarrow \mathrm{MeS}
$$

where $\mathrm{Me}^{2+}$ represents cationic metals, such as lead $(\mathrm{Pb})$, (cobalt) Co, cadmium (Cd), copper $(\mathrm{Cu})$, nickel (Ni), iron (Fe), and zinc (Zn) (Drury 1999; Zagury et al., 2006).

Acid mine drainage generally contains relatively low concentrations of dissolved organic $C(<10 \mathrm{mg} / \mathrm{l})$ 
(Kolmert \& Johnson 2001). Therefore, availability of $C$ from an additional organic source is the most critical limiting factor for microbial activity (Gibert et al., 2004; Zagury et al., 2006). Various types of organic substances have been studied as electron donors and C sources including sewage sludge, leaf mulch, wood chips, animal manure, vegetal compost, sawdust, mushroom compost, whey, and other agricultural waste (Waybrant et al., 1998). Due to their wide ranges of characteristics, they can result in different effectiveness in treating AMD. Chemical characteristics such as ratio of organic carbon and total nitrogen $(\mathrm{C} / \mathrm{N})$, availability of low-molecular weight compounds (Liamleam \& Annachhatre 2007), and adsorption sites have been identified to be responsible for remediation effects. High electrical conductivity (EC) has been found to have a strong correlation with high adsorption sites of the substrates (Gibert et al., 2004). Based on these, it is therefore, selection of suitable organic substrates for passive treatments is very important.

This laboratory study was aimed to characterize locally-available organic wastes (empty fruit bunch, bark, chicken manure, and sawdust) and explore their potential use for acid mine drainage remediation. It is roughly estimated that more than 20 million tons of empty fruit bunch is produced by palm oil industry in Indonesia and tend to increase annually (Isrori 2008). Bark is one of main solid wastes of pulp and paper industries (Purwati et al., 2007), chicken manure is produced by livestock industries and traditional farmers and commonly used as fertilizer in agriculture, while sawdust is produced by sawmills industry commonly found in surrounding areas of mine sites.

\section{MATERIALS AND METHODS}

This laboratory experiment was conducted in Soil Science Laboratory, the Department of Agronomy, University of Bengkulu, Bengkulu, Indonesia from March to November 2007.

Four different organic wastes were used in this study: bark of tree stem (BK), empty fruit buch of palm oil (EFB), sawdust (SD), and chicken manure (CM). The bark was supplied by a pulp and paper industry of Tanjung Enim Lestari Co., South Sumatra. Empty fruit bunch was collected from a crump palm oil (CPO) industry Bio Nusantara Co., Bengkulu, and the sawdust was obtained from a local sawmill industry in Bengkulu. Chicken manure was obtained from a local farm in Bengkulu. All these four organic waste materials were considered to be potentially suitable organic materials with respect to their availability. The acid mine drainage (AMD) was collected from Banko Barat Mine Unit of PT Tambang Batubara Bukit Asam (PERSERO) Tbk, Tanjung Enim, South Sumatra.

Characterization of Organic Wastes and Acid

Mine Drainage. All organic waste materials were airdried, and to obtain uniform size they were manually cut into $2-5 \mathrm{~cm}$ size, and passed through a $5 \mathrm{~cm}$ diameter sieve. They were brought to Soil Science Laboratory, Faculty of Agriculture, University of Bengkulu for analyses of total organic carbon $(C)$, total nitrogen $(\mathrm{N})$, total phosphorus $(\mathrm{P})$, total cations $(\mathrm{Ca}$, $\mathrm{Mg}, \mathrm{Na}, \mathrm{Mn}, \mathrm{Fe}$, and $\mathrm{Zn}$ ), cation exchange capacity (CEC), electrical conductivity (EC), and $\mathrm{pH}\left(\mathrm{H}_{2} \mathrm{O}\right)$ (Balai Penelitian Tanah 2005).

The chemical characterisations of AMD included measurements of $\mathrm{pH}$ and redox potential (Eh) and EC using electronic $\mathrm{pH}$-meter, lithium-electrode provided $\mathrm{pH} / \mathrm{mV}$-meter, and electrical conductivity-meter, respectively. Whereas concentrations of dissolved cations ( $\mathrm{Ca}, \mathrm{Mg}, \mathrm{Al}, \mathrm{Fe}$, and $\mathrm{Mn}$ ) and sulfate (SO4) analyses were determined using an Atomic Absorption Spectrophotometer and UV-Vis Spectrophotometer, respectively (Balai Penelitian Tanah 2005).

Remediation Effects of Organic Wastes on AMD Quality. An anaerobic bach experiment was conducted to test remediative effects of organic wastes to AMD. All individual organic wastes were weighed to obtain $250 \mathrm{~g}$ and put in the 2-L plastic containers and added with $1250 \mathrm{ml} \mathrm{AMD}$, with three replications. Organic materials were well mixed with AMD and containers were covered and allowed to anaerobically incubate at room temperature. A set of 4 extra containers containing same mixtures were prepared for destructive AMD samplings. During the experiment, $\mathrm{pH}$, redox potential (Eh), and EC of the mixtures were measured after the 1st, 7th, 14th, and 30th days of incubation. The AMD samples were taken from the extra containers for analyses of dissolved iron ( $\mathrm{Fe})$ and sulphates $\left(\mathrm{SO}_{4}{ }_{4}\right)$ concentrations. All measurement methods used in AMD characterization were also employed in this experiment.

\section{RESULTS AND DISCUSSIONS}

Organic Waste and AMD Characteristics, Organic wastes used in this experiment varied in their chemical properties and elemental compositions as shown in Table 1. Sawdust and bark were acidic with $\mathrm{pH}$ of 4.90 and 5.50 respectively, whereas the chicken 
Table 1. Chemical properties and elemental composition of the organic wastes.

\begin{tabular}{|c|c|c|c|c|}
\hline \multirow[b]{2}{*}{ Chemical properties: } & \multicolumn{4}{|c|}{ Organic wastes } \\
\hline & $\begin{array}{l}\text { Bark } \\
\text { (BK) }\end{array}$ & Chicken Manure (CM) & Empty Fruit Bunch (EFB) & $\begin{array}{l}\text { Sawdust } \\
\text { (SD) }\end{array}$ \\
\hline $\mathrm{pH}$ & 5.50 & 7.80 & 6.70 & 4.90 \\
\hline $\mathrm{EC}, \mu \mathrm{S} \mathrm{cm}^{-1}$ & 365 & 1645 & 2700 & 70 \\
\hline CEC, cmole $\mathrm{kg}^{-1}$ & 29.79 & 18.29 & 13.80 & 31.59 \\
\hline \multicolumn{5}{|l|}{ Elemental composition: } \\
\hline Total C, \% & 43.58 & 20.02 & 54.29 & 55.83 \\
\hline Total N, \% & 0.22 & 0.95 & 0.40 & 0.69 \\
\hline $\mathrm{C} / \mathrm{N}$ & 198.09 & 21.09 & 135.72 & 80.91 \\
\hline Total P, \% & 0.23 & 2.16 & 0.37 & 0.27 \\
\hline Total K, \% & 0.24 & 1.02 & 1.19 & 0.06 \\
\hline Total Ca, \% & 0.58 & 0.72 & 0.15 & 0.18 \\
\hline Total Mg, \% & 0.16 & 0.74 & 0.64 & 0.08 \\
\hline Total $\mathrm{Na}, \%$ & 0.17 & 0.53 & 0.65 & 0.14 \\
\hline Total Fe, $\mathrm{mg} \mathrm{L}^{-1}$ & 3500 & 13600 & 700 & 1800 \\
\hline Total $\mathrm{Mn}, \mathrm{mg} \mathrm{L}^{-1}$ & 117.07 & 417.22 & 53.27 & 4.79 \\
\hline Total $\mathrm{Zn}, \mathrm{mg} \mathrm{L}^{-1}$ & 6.88 & 283.36 & 77.43 & 42.05 \\
\hline
\end{tabular}

Table 2. Chemical properties of the AMD used in the study

\begin{tabular}{lcc}
\multicolumn{1}{c}{ Properties } & Unit & Values \\
\hline $\mathrm{pH}$ & - & 2.50 \\
Electrical conductivity (EC) & $\mu \mathrm{S} \mathrm{cm}$ & 1394.00 \\
Reduction-oxidation potential (Eh) & $\mathrm{mV}$ & 769.00 \\
Total dissolved calcium (Ca) & $\mathrm{mg} \mathrm{L}^{-1}$ & 33.73 \\
Total dissolved magnesium(Mg) & $\mathrm{mg} \mathrm{L}^{-1}$ & 83.31 \\
Total dissolved aluminium (Al) & $\mathrm{mg} \mathrm{L}^{-1}$ & 7.36 \\
Total dissolved iron (Fe) & $\mathrm{mg} \mathrm{L}^{-1}$ & 7.78 \\
Total dissolved manganese (Mn) & $\mathrm{mg} \mathrm{L}^{-1}$ & 3.54 \\
Total dissolved sulfate (SO4) & $\mathrm{mg} \mathrm{L}^{-1}$ & 407.28 \\
\hline
\end{tabular}

manure and empty fruit bunch tended to be alkaline with their respective $\mathrm{pH}$ of 7.80 and 6.70 . Elemental analyses found that the alkaline organic wastes generally contained higher macronutrients $(\mathrm{P}, \mathrm{K}, \mathrm{Ca}$, and $\mathrm{Mg}$ ) and some micronutrients compared to the acidic organic wastes. Organic wastes with higher $\mathrm{pH}$ and basic cations $(\mathrm{K}, \mathrm{Ca}, \mathrm{Mg}$, and $\mathrm{Na}$ ) had likely become potential sources of alkalinity for AMD treatments. As expected, higher nutrient element concentrations corresponded with higher EC values. Gibert et al., (2004) found that biodegradable substrates (poultry and sheep manures) more effective in removing $\mathrm{SO}^{4}$ from AMD than recalcitrant substrates, such as oak leaf. However, this study also demonstrated that although having lower degradability, bark and sawdust were able to improve AMD. Their higher cation exchange capacity (CEC) indicated that these substrates were able to retain higher amount of cations, such as potentially-hazardous metals contained on the exchange sites, removing the dissolved cations in the AMD.
Nutrient analyses also revealed that total organic C was lower in chicken manure (20.02\%) compared to the other organic wastes ranging between $43 \%$ and $60 \%$. On the other hand, the chicken manure contained highest total $\mathrm{N}$ content $(0.95 \%)$. These variations resulted in wide ranges of $\mathrm{C} / \mathrm{N}$ ratios of the organic wates, between 21 and 200. The chicken manure had lowest $\mathrm{C} / \mathrm{N}$ ratio (21.09), whereas wood bark had highest (198.09). Earlier studies by Gibert et al., (2004) reported that a maximum $\mathrm{C} / \mathrm{N}$ ratio for sulfate-reducing bacteria (SRB) was in the range of $45-120$. Lower $\mathrm{C} / \mathrm{N}$ ratio may suggest a lack of $C$, whereas higher ratios indicate excessive $\mathrm{C}$ or $\mathrm{N}$ deficiency. Therefore, although chicken manure was highest in alkalinity and nutrient elements, it might not sufficiently provide $C$ for long-term support for SRB in reducing $\mathrm{SO}^{4}$. On the other hand, organic wastes with very high $\mathrm{C} / \mathrm{N}$ ratios such as bark and empty fruit bunch might have sufficient $C$, but they are not easily degradable due to possible high lignin content. Therefore, Liamleam and Annachhatre (2007) recommended that a preferred organic electron donor and $\mathrm{C}$ source consist of more than one type of electron donors to obtain best performance of $\mathrm{SO}^{4}$ reduction by SRB. Mixtures containing multiple organic substances have been reported to be higher in sulfate reducing rates compared with those containing a single organic substrate (Waybrant et al., 1998).

Data in Table. 2 show that acid mine drainage (AMD) used in this experiment was very acidic ( $\mathrm{pH} 2.5)$, high dissolved oxygen (high positive Eh) and EC, low 
in dissolved basic cations ( $\mathrm{Ca}$ and $\mathrm{Mg}$ ), moderate to fairly high dissolved acidic cations ( $\mathrm{Al}, \mathrm{Fe}$, and $\mathrm{Mn}$ ) and sulfate $\left(\mathrm{SO}^{4}\right)$ concentrations. These characteristics suggest that treatment methods for this AMD should involve additions of alkaline materials and materials which are able to create reducing conditions for removing potentially-hazardous metals and $\mathrm{SO}^{4}$. The following section discusses the changes of AMD properties as affected by additions of the organic wastes under anaerobic condition.

Remediative Effects of Organic Wastes in Anaerobic Incubation. All organic wastes significantly increased $\mathrm{pH}$ of the AMD (Figure 1a) from its original $\mathrm{pH}$ (2.5). However, the increments varied among the organic materials over the entire experiment, depending on their properties. The increment in $\mathrm{pH}$ of AMD well correlated with original $\mathrm{pH}$ of the organic wastes. During the experiment chicken manure-AMD mixture had constantly highest $\mathrm{pH}(>7)$, followed by empty fruit bunch $(\mathrm{pH}>6)$. On the contrary, the $\mathrm{pH}$ of sawdust-AMD mixture was constantly lower than acceptable $\mathrm{pH}$ value (6). High contents of basic cations such as $\mathrm{Ca}, \mathrm{Mg}$, and $\mathrm{Na}$ in the chicken manure and empty fruit bunch apparently correlated with the increase in $\mathrm{pH}$ of AMD. Higher concentrations of nutrient elements in these organic materials and by high EC (Figure 1b) might have enhanced biological activity, resulting in high oxygen consumption which then created reduced conditions (Eh more negative) during the entire incubation (Figure 1c) and consequently increased alkalinity. Gibert et al., (2004) found that the lower the content of lignin in the organic substrate such as sheep manure, the higher its biodegradability and capacity for developing bacterial activity. Such reactions demand oxygen due to increasing metabolic process (CunhaSantino \& Bianchini 2006), such as re-oxidation of anaerobic respiration (Hansen \& Blackburn 1991). Although not as much reduction as in the chicken manure- and empty fruit bunch-AMD mixtures, additions of the other two organic wastes had also significantly decreased Eh, particularly after the second week of incubation.

In general additions of organic wastes had significantly decreased dissolved Fe concentrations in AMD as shown in Figure 2a. Decrease in the dissolved Fe was greater under sawdust and bark-AMD mixtures compared with that under chicken manure- and empty fruit bunch-AMD mixtures, although the later had more reduced conditions. This unexpected phenomenon
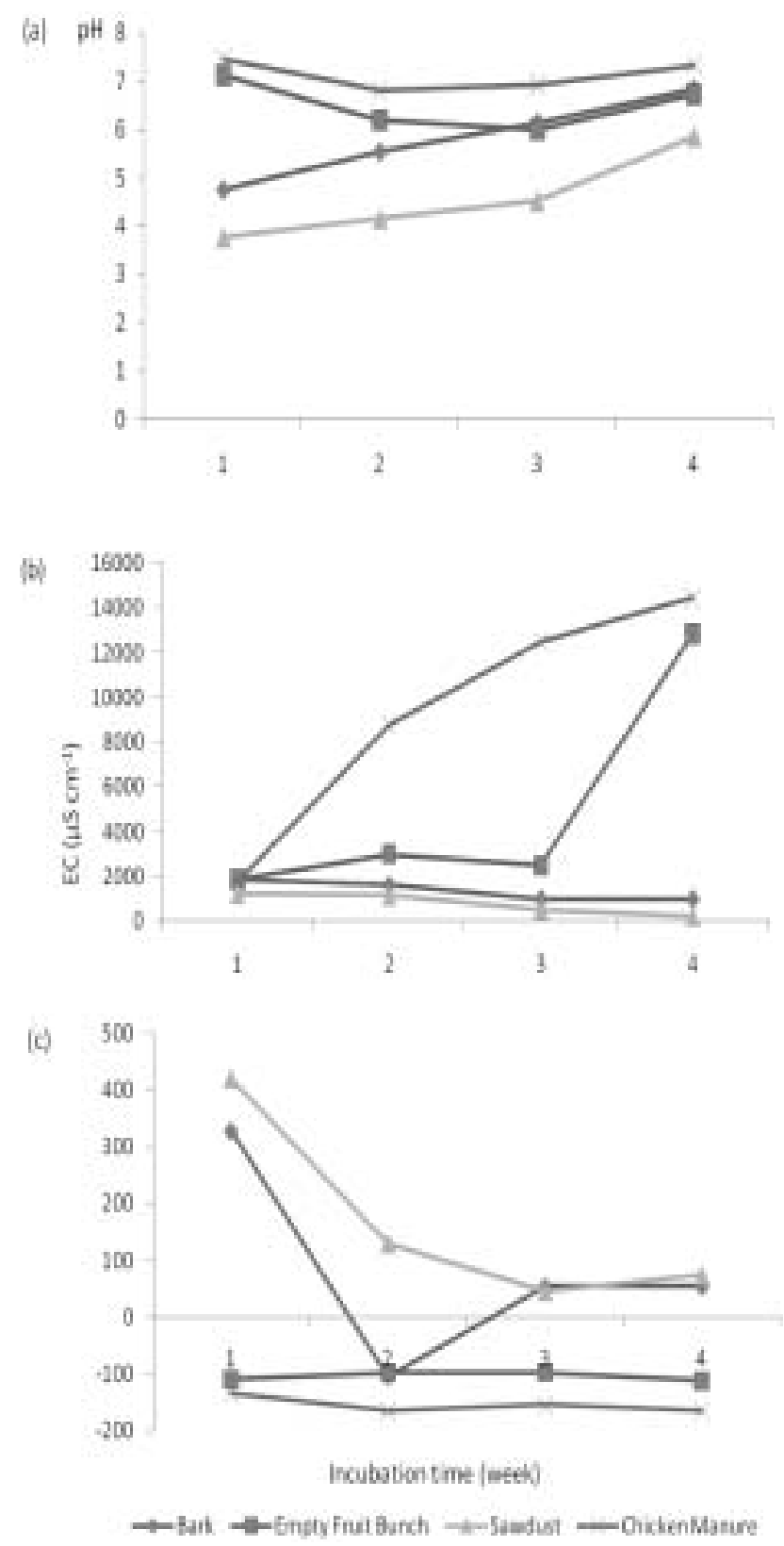

Figure 1. Changes in (a) pH, (b) electrical conductivity (EC), and (C) redox potential (Eh) of the AMD as affected by organic wastes additions during the incubation time

could clearly be explained by Figure $2 b$. Figure $2 b$ shows that the initial reducing condition (decline in Eh) developed in the first two weeks (between -100 and $200 \mathrm{mV}$ ) in the chicken manure- and empty fruit bunchAMD mixtures was not sufficiently able to reduce significant amounts of $\mathrm{SO}^{4}$ to form Fe-sulfides. Reduction of $\mathrm{SO}^{4}$ apparently occurred later after the third week of incubation. Based on this fact, the decrease in Fe concentrations (Figure 2a) compared to the original AMD $\left(7.78 \mathrm{mg} \mathrm{l}^{-1}\right)$ in the first two week was not due to precipitation of Fe-sulfide, but more likely due to Fe retention to organic matter. The sawdust and bark materials, which had higher CEC as shown in Table 
1 , were able to retain more $\mathrm{Fe}$, resulting in lower dissolved Fe concentrations (Figure 2a). Zagury et al., (2006) explained that metal removal tends to occur earlier compared with $\mathrm{SO}^{4}$ reduction, through adsorption of the metals onto organic matter. Once reduced conditions are established, sulfide metal precipitation becomes predominant mechanism of the metal removal from AMD (Song et al., 2001; Zagury et al., 2006), resulting in alkalinity production.

Sulfate reduction into metal-sulfides such as Feand Zn-sulfides might have occurred in the third week, as indicated by declining SO4 concentration (Figure $2 b)$. Higher SO 4 concentration in the chicken manureAMD mixture was probably due to released $\mathrm{SO} 4$ salts over incubation period, yielding high EC (Figure 1c). Although $\mathrm{SO}^{4}$ concentration was not further measured after third week, given trends of the curves, reducing condition would likely take place further beyond this period. Therefore, if metals such as Fe and $\mathrm{Zn}$ were adequately available, formation of metal-sulfides would occur. Good performance of manure for AMD remediation has been reported in a number of studies elsewhere. Gibert et al., (2004) observed that seep manure was successful for creating reduced condition and sustaining sulfide generations by removing $99 \% \mathrm{SO}^{4}$.

The complex organic $\mathrm{C}$ source (sawdust) did not perform well compared to other organic wastes in AMD remediation. Although higher than original values, the $\mathrm{pH}$ of sawdust-AMD mixture was constantly lower than the acceptable value $(\mathrm{pH} 6)$. Sawdust has been considered as recalcitrant compound or cellulosic waste (Neculita et al., 2007); therefore, it did not easily react with AMD. Marschner and Kalbitz (2003) found that the recalcitrant fraction remains in the solution up to 180 days of incubation. Low EC and nutrient concentrations of the sawdust (Table 1) were likely unfavourable for microbial activity, as indicated by relatively constant and high (positive) Eh values during the experiment. Similar data were also reported by other investigators (Cocos et al., 2002; Figueroa et al., 2004; and Zagury et al., 2005). They suggested, therefore, that balanced mixtures of organic materials containing high organic acid and saccharide fractions quickly consumed by sulphate-reducing bacteria (SRB) such as manures, with more recalcitrant compounds (lignocelluloses) such as sawdust and wood chips result in sustained SRB. Therefore, although sawdust and other similar materials do not individually remediate AMD, additions of these materials into fertile organic wastes like chicken manure is necessary to provide long-term $C$ source for SRB and favorable physical properties of the organic matter for AMD treatment (Cocos et al., 2002). Zagury et al., (2007) stated that the most efficient mixtures usually contain relatively easily biodegradable sources, such as manure and sludge, and recalcitrant ones, such as sawdust and wood chips.

\section{CONCLUSIONS}

Organic wastes varied in their properties and performed differently in treating AMD. Organic wastes containing high alkalinity (high $\mathrm{pH}$ ) and nutrient concentrations (chicken manure and empty fruit bunch) improved AMD quality through increasing $\mathrm{pH}(>6)$ and reducing $\mathrm{Fe}$ and $\mathrm{SO}^{4}$ concentrations. Although sawdust and bark did not significantly increase $\mathrm{pH}$ up to acceptable standard, they apparently were able to remove dissolved Fe from AMD possibly through adsorption mechanism. In summary, all these organic wastes are potential for biological treatments of AMD.

Based on the results of this study and results from other investigators described above, it is necessary to further study on quantitative measures of detailed compositions of the organic wastes and their appropriate mixtures used for anaerobic treatment systems which rely on sulfate-reducing mechanism by SRB.

\section{ACKNOWLEGMENTS}

We acknowlewdge the finacial support from the Directorate General of Higher Education, the Department of National Education of the Republic of Indonesia under Fundamental Research Grant 2007 and thank PT Tambang Batubara Bukit Asam (PERSERO) Tbk, Tanjung Enim, South Sumatra for supplying AMD. We also gratefully thank PT Bio Nusantara, Bengkulu and PT Tanjung Enim Lestari, Tanjung Enim for providing organic wastes. The authors also wish to thank Lea, Vefthy, and Wijayanti for their valuable helps during the experiment.

\section{REFERENCES}

Balai Penelitian Tanah. 2005. Petunjuk teknis analisis kimia tanah, tanaman, air, dan pupuk. Balai Penelitian Tanah, Badan Penelian dan Pengembangan Pertanian, Departemen Pertanian. 136p.

Cocos, I., G. Zaury, B. Clement, R. \& Samson. 2002. Multiple factor design for reactive mixture selection for use in reactive walls in mine drainage treatment. Water Research 32, 167177. 
Cunha-Santino, M.B. \& J.R. Bianchini. 2006. The aerobic an anaerobic decomposition of Typha domingenis Pers. Acata. Limnol. Bras 18(3): 321-334.

Drury, W.J. 1999. Treatment of acid mine drainage with anaerobic solid-substrate reactors. Water Environment Res. 71: 12441250.

Figueroa, L., J. Seyler. \& T. Wildeman. 2004. Characterization of organic substrates used for anaerobic bioremediation of mining impacted waters. Jarvis, A (Ed). Proceedings, International Mine Water Association Conference. September 25, 2004, New Castle, England, p. 43-52.

Gibert, O., J.D. Pablo, J.L. Cortina, C. \& Ayora. 2004. Chemical characterization of natural organic substrates for biological mitigation of acid mine drainage. Water Research 38: 41864196.

Hansen, L.S. \& T.H. Blackburn. 1991. Aerobic and anaerobic mineralization of organic material in marine sediment microcosms. Mar. Ecol. Prog. Ser. 73: 283-291.

Isrori. 2008. Potensi biomassa lignoselulosa di Indonesia sebagai bahan baku bioetanol: tandan kosong kelapa sawit. http:// isroi.wordpress.com/2008/04/29/potensi-biomassalignoselulosa-di-indonesia-sebagai-bahan-bakubioetanoltandan-kosong-kelapa-sawit/

Kolmert, A. \& D.B. Johnson. 2001. Remediation of acidic waste waters using immobilized, acidophilic sulfate-reducing bacteria. J. Chem. Technol Biotechnol. 76: 836-843.

Liamleam, W. \& A.P. Annachhatre. 2007. Electron donors for biological sulfate reduction. Biotechnology Advanced 25: 452-463.

Luptakova, A. \& M. Kusnierova. 2005. Bioremediation of acid mine drainage contaminated by SRB. Hydrometallurgy. 77 : 97-102.
Machemer, S.D. \& T.R. Wildeman. 1992. Adsorption compared with sulphide precipitation as metal removal processes from acid mine drainage in a constructed wetland. Journal of Contaminant Hydrology. 9: 115-131.

Marschner, B. \& K. Kalbitz. 2003. Controls of bioavailability and biodegradability of dissolved organic matter in soils. Geoderma 113: 211-235.

Neculita, C., G.J. Zagury. \& B. Bussiere. 2007. Efficiency of three reactive mixtures of organic wastes for the treatment of highly contaminated acid mine drainage. OttawaGeo2007, 1530-1537.

Purwati, S, R. Soetopo, Y. \& Setiawan. 2007. Potensi penggunaan abu broiler pulp dan kertas sebagai bahan pengkondisi tanah tanah gambut pada areal hutan tanaman industry. Berita Selulosa 42(1): 8-17.

Song, Y., M. Fitch, J. Burken, L. Nass, S. Chilukiri, N. Gale, C. \& Ross. 2001. Lead and zinc removal by laboratoryscale constructed wetland. Water Environment Res. 7: 3744.

Waybrant, K.R., D.W. Blowes. \& C.J. Ptacek. 1998. Selection of reactive mixtures for uses in permeable rective walls for treatment of mine drainage. Environ. Sci. Technol. 32: 19721979.

Zagury, G.J., V.I. Kulnieks. \& C.M. Neculita. 2006. Characterization and reactivity assessment of organic substrates for sulphate-reducing bacteria in acid mine drainage treatment. Chemosphere 64: 944-954.

Zagury, G.J., C. Neculita. \& B. Bussiere. 2007. Passive treatment of acid mine drainage in bioreactors: short review, application, and research needs. Ottawa Geo2007, 1443914446. 